\title{
Faktor-faktor yang Memengaruhi Efektivitas Sistem Informasi Akuntansi Lembaga Perkreditan Desa se-Kecamatan Tegallalang
}

\author{
Ni Wayan Wahyu Kusumaningsih 1 \\ Fakultas Ekonomi dan Bisnis Universitas \\ Udayana, Indonesia. \\ Email: wahyukusumaningsih13@gmail.com
}

\author{
Ida Bagus Dharmadiaksa2 \\ Fakultas Ekonomi dan Bisnis \\ Universitas Udayana, Indonesia.
}

\begin{abstract}
ABSTRAK
Penelitian ini bertujuan untuk mengetahui faktor-faktor yang mempengaruhi efektivitas SIA berbasis komputer dengan menggunakan model TAM. Penelitian ini bertempat di LPD Kecamatan Tegallalang. Metode pengambilan sampel menggunakan teknik purposive sampling. Data penelitian diperoleh melalui metode survei dengan teknik kuesioner. Analisis data penelitian menggunakan regresi linear berganda. Hasil penelitian yaitu sesuai dengan teori TAM yang digunakan yaitu kualitas sistem informasi, kecanggihan teknologi dan kemampuan teknik personal yang merepresentasikan kegunaan dalam teori TAM akan mempengaruhi persepsi personal untuk menerima dan menggunakan teknologi, sehingga akan berpengaruh positif pada efektivitas SIA berbasis computer. Berdasarkan hasil penelitian LPD diharapkan meningkatkan pelatihan penggunaan sistem informasi akuntansi sehingga keterampilan pegawai dalam menggunakan sistem menjadi lebih baik sehingga pekerjaan menjadi lebih efisien.
\end{abstract}

Kata Kunci: TAM; Kualitas Sistem Informasi; Kecanggihan Teknologi; Kemampuan Teknik Personal.

\section{Factors Affecting the Effectiveness of Accounting Information Systems in Rural Credit Institutions in Tegallalang District}

\begin{abstract}
This study aims to determine the factors that influence the effectiveness of information systems computer-based by using the TAM model. This research took place at the Tegallalang District LPD. The sampling method uses purposive sampling technique. Research data was obtained through survey methods with questionnaire techniques. Analysis of research data using multiple linear regression. The results of the study are in accordance with the TAM theory that is use namely the quality of information systems, technological sophistication and the ability of personal techniques that represent usability in TAM theory will affect personal perceptions to accept and use technology, so that it will positively affect the effectiveness of computer-based AIS. Based on the results of LPD research, it is expected to improve training in the use of accounting information systems so that the skills of employees in using the system become better so that work becomes more efficient.
\end{abstract}

Keywords: TAM; Quality Of Information Systems; Technological Sophistication; Personal Technical Capabilities.

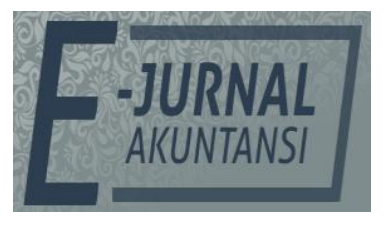

E-JA

e-Jurnal Akuntansi e-ISSN 2302-8556

Vol.298 No. 1 Denpasar, Oktober 2019

Hal. 205-224

Artikel masuk: 10 Agustus 2019

Tanggal diterima: 29 September 2019 


\section{PENDAHULUAN}

Peran teknologi informasi menjadi salah satu fasilitas utama perusahaan untuk menghasilkan informasi yang berkualitas yang sekaligus menjadi salah satu strategi bisnis bagi perusahaan (Hendarti \& Gui, 2008). Menurut McLeod (1996) informasi adalah salah satu jenis sumber daya yang utama yang tersedia bagi manajemen. Kualitas informasi yang baik merupakan salah satu keunggulan yang dimiliki oleh perusahaan. Informasi yang tepat dan akurat sangat dibutuhkan oleh pihak manajemen dalam hal pengambilan keputusan. Untuk menghasilkan informasi yang akurat sangat dibutuhkan bantuan teknologi dalam mengolahnya. Keberadaan teknologi informasi bertujuan untuk membantu manusia dalam memproses data yang diperlukan oleh pihak internal dan eksternal. Sistem informasi akuntansi (SIA) membantu dalam hal membuat laporan eksternal, mendukung aktivitas rutin, mendukung pengambilan keputusan, perencanaan dan pengendalian serta menerapkan pengendalian internal. Sistem informasi akuntansi merupakan bagian yang sangat penting untuk meningkatkan efisiensi organisasi dan mendukung daya saing dengan menyediakan informasi keuangan dan akuntansi bagi manajemen (Alsarayreh et al.,2011). Menurut DeLone dan McLean (1992). cara pengukuran efektivitas SIA salah satunya yaitu kualitas informasi yang mencakup di dalamnya ketepatan waktu.

Pada jaman teknologi seperti sekarang ini sudah banyak LPD yang beralih dari sistem manual ke sistem berbasis komputer dan telah menerapkan SIA berbasis aplikasi komputer dalam pengolahan datanya. Berdasarkan Peraturan Gubernur Bali No 11 Tahun 2013 Pasal 1, disebutkan Lembaga Perkreditan Desa (LPD) adalah lembaga keuangan milik Desa Pakraman yang bertempat di wilayah Desa Pakraman. Saat ini 16 LPD di Kecamatan Tegallalang dari total 45 LPD yang ada di Kecamatan Tegallalang sudah menerapkan SIA berbasis aplikasi komputer karena berfungsi sebagai back-up dan perbandingan dengan laporan keuangan secara manual. Menurut data yang diperoleh dari LPLPD Kabupaten Gianyar, dari 16 LPD yang sudah menggunakan SIA berbasis aplikasi komputer terdapat beberapa LPD yang terlambat melaporkan laporan keungan bulanannya ke LPLPD Kabupaten Gianyar selama tahun 2018. Dimana syarat pelaporan laporan keungan bulanan LPD ke LPLPD yaitu selambatlambatnya tanggal 10 bulan berikutnya. Data LPD tersebut yaitu sebagai berikut.

Tabel 1. LPD yang terlambat melaporkan laporan keuangan tahun 2018

\begin{tabular}{cll}
\hline No & Nama LPD & Status Pelaporan \\
\hline 1 & Alas Pujung & Terlambat $2 \mathrm{x}$ \\
2 & Bayad Tegallalang & Tepat waktu \\
3 & Belong & Terlambat $1 \mathrm{x}$ \\
4 & Bonjaka & Tepat waktu \\
5 & Kedisan & Tepat waktu \\
6 & Manuaba & Tepat waktu \\
7 & Mumbi & Tepat waktu \\
8 & Perean & Tepat waktu \\
9 & Pupuan & Terlambat $1 \mathrm{x}$ \\
\hline
\end{tabular}

Bersambung... 
Lanjutan Table 1.

\begin{tabular}{lll}
\hline 10 & Sapat & Tepat waktu \\
11 & Taro Kaja & Tepat waktu \\
12 & Taro Kelod & Tepat waktu \\
13 & Tatag & Tepat waktu \\
14 & Tebuana & Terlambat $2 \mathrm{x}$ \\
15 & Tegal Payang & Tepat waktu \\
16 & Tegallalang & Tepat waktu \\
\hline
\end{tabular}

Sumber: LPLPD Kabupaten Gianyar, 2019

Data di atas menunjukkan bahwa terdapat 4 LPD yang sudah menggunakan SIA berbasis aplikasi komputer yang pernah terlambat dalam melaporkan laporan keuangan tiap bulannya ke LPLPD Kabupaten Gianyar. Menurut DeLone dan McLean (1992). cara pengukuran efektivitas SIA salah satunya yaitu kualitas informasi yang mencakup di dalamnya yaitu ketepatan waktu pelapoan keuangan. Berdasarkan observasi awal, dari 4 LPD yang pernah terlambat melaporkan laporan keuangan ke LPLPD Kabupaten Gianyar, 3 diantaranya yaitu LPD Alas Pujung, LPD Belong dan LPD Pupuan mengungkapkan alasan keterlambatannya yaitu karena faktor Sumber Daya Manusia (SDM), dimana karyawan masih kurang percaya diri dalam pengoperasian SIA yang ada karena sebelumnya mereka mengelola data dengan proses manual. Selain itu lemahnya kualitas sistem informasi akuntansi pada LPD tersebut yaitu sistem yang terinstal pada komputer sering kali mengalami kemacetan sehingga proses data keuangan menjadi terhambat.

Efektivitas penerapan sistem informasi akuntansi (SIA) dalam sebuah perusahaan dapat dipengaruhi dari berbagai faktor. Choe (1996) mengungkapkan bahwa terdapat beberapa faktor yang berpengaruh terhadap kinerja sistem informasi akuntansi, yaitu keterlibatan pemakai, kemampuan pemakai sistem informasi, dan ketentuan pelatihan dan pendidikan pemakai sistem informasi. Fung (2002) dalam penelitiannya menyebutkan delapan faktor yang digunakan dalam pengukuran kinerja SIA, yaitu keterlibatan pemakai dalam pengembangan sistem, kemampuan teknik personal sistem informasi, ukuran organisasi, dukungan manajemen puncak, formalisasi pengembangan sistem informasi, program pelatihan dan pendidikan pemakai, keberadaan dewan pengarah sistem informasi dan lokasi dari departemen sistem informasi. Namun pada Penelitian ini pneliti menggunakan tiga variabel bebas yaitu kualitas sistem informasi, kecanggihan teknologi dan kemampuan teknik personal karena sesuai dengan permasalahan yang telah dipaparkan sebelumnya.

Kualitas sistem berarti kombinasi hardware dan software dalam sistem informasi. Fokusnya adalah performa dari sistem, merujuk pada seberapa baik kemampuan perangkat keras, perangkat lunak, kebijakan, prosedur dari sistem informasi dapat menyediakan kebutuhan pengguna (DeLone \& McLean 1992). Pada peneliti sebelumnya, penelitian yang dilakukan oleh Isti (2016).. menyimpulkan bahwa kualitas sistem informasi akuntansi berpengaruh positif terhadap kepuasaan pengguna. Penelitian yang dilakukan oleh Sri (2016) juga menyimpulkan bahwa kualitas sitem informasi berpengaruh positif pada 
kepuasaan pengguna akhir software akuntansi. Sedangkan penelitian dari Suroso (2017). Menyimpulkan bahwa kualitas sistem informasi tidak berpengaruh pada kinerja BPR di Kalimantan Timur.

Penggunaan teknologi komputer dan internet merupakan salah satu bentuk teknologi informasi yang mampu mengubah proses data secara manual menjadi secara digital dan otomatis (Suhardiyah dan Waryanto, 2014). Hasilhasil penelitian sebelumnya yaitu penelitian dari Ismail (2009) menyimpulkan bahwa kecanggihan SIA tidak berpengaruh signifikan terhadap efektivitas SIA. Perbedaan hasil didapat dari penelitian Dwitrayani (2012) dan Ratnaningsih (2014) yang menyimpulkan bahwa kecanggihan teknologi informasi berpengaruh positif dan signifikan terhadap efektivitas sistem informasi akuntansi.

Hasl-hasil dari penelitian sebelumnya yaitu penelitian Abhimantra, et. al.(2016) menyimpulkan bahwa kemampuan teknik personal berpengaruh pada kinerja sistem informasi akuntansi pada BPR di Kota Denpasar. Penelitian yang dilakukan oleh Adisanjaya, et. al. (2017) juga menyimpulkan terdapat pengaruh positif dan signifikan antara kemampuan teknik personal terhadap efektivitas sistem informasi akuntansi. Perbedaan hasil ditunjukkan pada penelitian Dharmawan (2017) yang menyimpulkan bahwa kemampuan teknik personal tidak berpengaruh positif terhadap kinerja efektivitas sistem informasi akuntansi.

Lokasi penelitian pada LPD Kecamatan Tegallalang dipilih karena dari segi ekonomi, masyarakat lebih cenderung bergerak dalam bidang perdagangan dan industri kerajinan sehingga keberadaan LPD sangat diperlukan untuk membantu permodalan dalam usaha. Selain itu, perkembangan LPD di Kecamatan Tegallalang sangat berkembang maka sistem informasi akuntansi yang efektif sangat penting untuk meningkatkan pelayanan kepada nasabah dan untuk memproses data transaksi yang lebih cepat, akurat dan tepat waktu sehingga LPD di Kecamatan Tegallalang mampu menghadapi persaingan yang telah cukup ketat. Terjadinya kondisi persaingan yang semakin kompetitif juga menjadi alasan pemilihan lokasi karena telah banyak lembaga keuangan selain LPD seperti koperasi berkembang di Kecamatan Tegallalang. Jumlah koperasi yang bergerak di bidang simpan pinjam di Kecamatan Tegallalang berjumlah 153 koperasi, dimana jumlah tersebut lebih banyak dari jumlah LPD di Kecamatan Tegallalang yaitu 45 LPD.

Teori TAM diadopsi dari Theory of Reasoned Action (TRA), yaitu teori yang menjelaskan bahwa persepsi seseorang terhadap sesuatu akan menentukan sikap dan perilaku orang tersebut. TAM pertama kali diperkenalkan oleh DAVIS pada tahun 1989. Teori ini menjelaskan bahwa terdapat dua faktor yang mempengaruhi perilaku personal untuk menerima dan menggunakan teknologi. Dua faktor tersebut adalah kemanfaatan (usefulness) dan kemudahan penggunaan (ease of use) (Surendran, 2012).

Teori TAM menyatakan bahwa kemanfaatan dan kemudahan penggunaan akan mempengaruhi perilaku personal untuk menerima dan menggunakan teknologi. Ketika personal mampu menggunakan SIA, maka personal tersebut akan mendapatkan manfaat dan kemudahan dalam menggunakan SIA berbasis program aplikasi. Semakin meningkatnya 
pemahaman personal terhadap SIA maka personal akan mampu menunjukan masalah dan hal-hal tertentu untuk perbaikan SIA (Havelka, 2004). Sehingga penerapan SIA akan menjadi efektif. Maka dari itu, sesuai dengan teori TAM, kemampuan teknik personal merepresentasikan kemanfaatan dan kemudahaan penggunaan dalam teori TAM.

Kaitan Teori TAM dengan variabel kualitas SIA dan Kecanggihan Teknologi yang digunakan, yaitu menurut Isti (2016). ketika suatu sistem dikatakan berkualitas maka sistem tersebut akan bermanfaat. Begitu juga jika suatu sistem menggunakan teknologi yang canggih maka manfaat dari sistem tersebut juga akan meningkat. Karena kecanggihan teknologi tersebut menghasilkan beraneka ragam teknologi sistem yang dirancang untuk membantu pekerjaan manusia dalam menghasilkan informasi yang terbaik. Keanekaragaman teknologi tersebut memberikan kemudahan bagi para pengguna teknologi dalam implementasinya (Ratnaningsih, 2014). Kemudahan pengguna dan kemanfaatan ini sesuai dengan teori TAM akan mempengaruhi perilaku personal untuk menerima dan menggunakan sistem tersebut, sehingga penggunaan SIA akan menjadi efektif (Surendran, 2012). Maka dari itu, variabel kualitas sistem dan kecanggihan teknoloi dalam penelitian ini merepresentasikan kemanfaatan dalam teori TAM.

Menurut Hall (2011: 5). sistem merupakan kumpulan atau kelompok yang terdiri dari dua atau lebih komponen-komponen yang saling berhubungan atau subsistem-subsistem untuk mencapai tujuan yang sama. Informasi adalah data yang dikelola dan diproses untuk memberikan arti dan memperbaiki proses pengambilan keputusan. Sebagaimana perannya, pengguna membuat keputusan yang lebih baik sebagai kuantitas dan kualitas dari peningkatan informasi. Menurut (Romney \& Steinbart, 2015:4). karakteristik informasi yang berguna adalah relevan, reliabel, lengkap, Tepat waktu, dapat dipahami, dan dapat diverifikasi, dapat diakses.

Sistem Informasi Akuntansi (SIA) merupakan kumpulan sumber daya, seperti manusia dan peralatan, yang dirancang untuk mengubah data keuangan dan data lainnya ke dalam informasi (Bondnar \& Hopwood, 2010:1).. SIA merupakan suatu sistem yang mengumpulkan, mencatat, menyimpan,dan mengolah data untuk menghasilkan informasi bagi pengambilan keputusan (Romney \& Steinbart, 2015:10).

Menurut DeLone \& McLean (2003). Model Kesuksesan Sistem Informasi mulai dikembangkan pada tahun 1992, yang didasarkan pada proses dan hubungan kausal dari enam dimensi pengukur yaitu : Information quality (kualitas informasi), berkaitan dengan output sistem informasi. Kualitas informasi diukur dalam hal akurasi, ketepatan waktu, kelengkapan, relevansi, dan konsistensi. Dampak individunya diukur dalam hal pengambilan keputusan, efektivitas kerja, dan kualitas kerja. System quality (kualitas sistem), terkait mengenai kualitas atas sistem informasi yang digunakan. Kualitas sistem diukur dalam hal kemudahan penggunaan, fungsionalitas, kehandalan, fleksibilitas, kualitas data, integrasi dan peran pentingnya dalam suatu organisasi. Dampak individunya diukur sebagai kualitas lingkungan kerja dan prestasi kerja. 
Definisi kualitas yang paling sering disebutkan adalah bahwa kualitas merupakan kemampuan mencapai tujuan dan penyesuaian kebutuhan antara pengguna dan pelanggan. Kebutuhan dan karakteristik berperan penting dalam mendefinisikan suatu kualitas (Yuadi, 2008). Setiap pemakai saling berlainan dalam memahami, merasakan, dan menilai apa itu kualitas. Konsep kualitas tersebut didefinisikan oleh para ahli dari berbagai sudut pandang. Pada model kesuksesan sistem informasi yang dikemukakan oleh DeLone \& McLean (1992) menyebutkan bahwa kualitas sistem (system quality) merupakan pengukuran kesuksesan teknikal, kualitas informasi merupakan ukuran keberhasilan semantik, kepuasan pengguna mengambarkan pengaruh individu dan organisasi yang merupakan ukuran efektivistas kesuksesan. Menurut DeLone \& McLean (1992) beberapa peneliti kualitas sistem dapat diukur melalui ease of use, functionality, reliability, flexibility, data quality, portability, integrity dan importance.

Kecanggihan teknologi di masa kini memiliki perkembangan yang pesat bahkan mampu menghasilkan beraneka ragam teknologi sistem yang dirancang untuk membantu pekerjaan manusia dalam menghasilkan kualitas informasi terbaik. Keanekaragaman teknologi tersebut memberikan kemudahan bagi para pengguna teknologi dalam implementasi. Perusahaan yang memiliki teknologi informasi yang canggih (terkomputerisasi dan terintegrasi) dan didukung oleh aplikasi pendukung teknologi modern, diharapkan dapat memberikan dampak positif bagi kelangsungan kinerja perusahaan dengan menghasilkan laporan keuangan yang tepat waktu, akurat, dan dapat dipercaya.

Definisi kecanggihan teknologi informasi menurut Raymond \& Pare dalam Granell (2014:57). adalah: "Information technology sophistication is defined as multi-dimensional construct which refers to the nature, complexity and interdepedence of information technology usage and management in an organisation. Therefore, the concept of information technology sophistication integrates both aspects related to System Information usage and System Information management".

Berdasarkan definisi di atas dapat diketahui bahwa, kecanggihan teknologi informasi sebagai multi-dimensi yang mengacu pada sifat, kompleksitas dan interdependensi penggunaan teknologi informasi dan manajemen dalam suatu organisasi. Oleh karena itu, konsep kecanggihan teknologi informasi mengintegrasikan kedua aspek yang berkaitan dengan menggunakan sistem informasi dan sistem informasi manajemen.

Kemampuan teknik personal adalah kemampuan yang dimilki seseorang yang diperoleh dari pengalaman dan dari pendidikan atau pelatihan yang pernah diikuti sehingga dapat meningkatkan kepuasannya untuk menggunakan SIA yang diterapkan oleh suatu organisasi (Kameswara 2013). Hary (2014). menyatakan bahwa kemampuan teknik pemakai yang baik dapat mendorong pemakai untuk menggunkana SIA sehingga kinerja SIA lebih tinggi. Pemakai SIA yang memiliki kemampuan teknik yang baik akan meningkatkan kepuasannya dalam menggunakan SIA sehingga terus menggunakannya dalam membantu menyelesaikan pekerjaannya karena pemakai memiliki pengetahuan kemampuan yang memadai.

Berdasarkan Peraturan Gubernur Bali No 11 Tahun 2013 Pasal 1, menyebutkan Lembaga Perkreditan Desa (LPD) adalah lembaga keuangan milik Desa Pakraman yang bertempat di wilayah Desa Pakraman LPD bertujuan 
memberi pelayanan kepada nasabah serta lingkungan yang terkait. Lembaga keuangan seperti LPD dalam prakteknya bersaing ketat dengan lembaga keuangan lainnya seperti Bank Perkreditan Rakyat (BPR), koperasi, dan lain sebagainya, sehingga LPD dituntut untuk terus meningkatkan pelayanannya. Salah satu cara meningkatkan pelayanan suatu LPD adalah melalui peningkatan efektivitas SIA LPD tersebut. Tujuan didirikannya sebuah LPD adalah untuk mendorong pembangunan ekonomi masyarakat desa melalui pemberian kredit maupun simpanan dalam bentuk tabungan. Selain itu dengan didirikannya sebuah LPD akan membantu menciptakan pemerataan kesejahteraan dan membantu menciptakan kesempatan berusaha bagi warga desa.

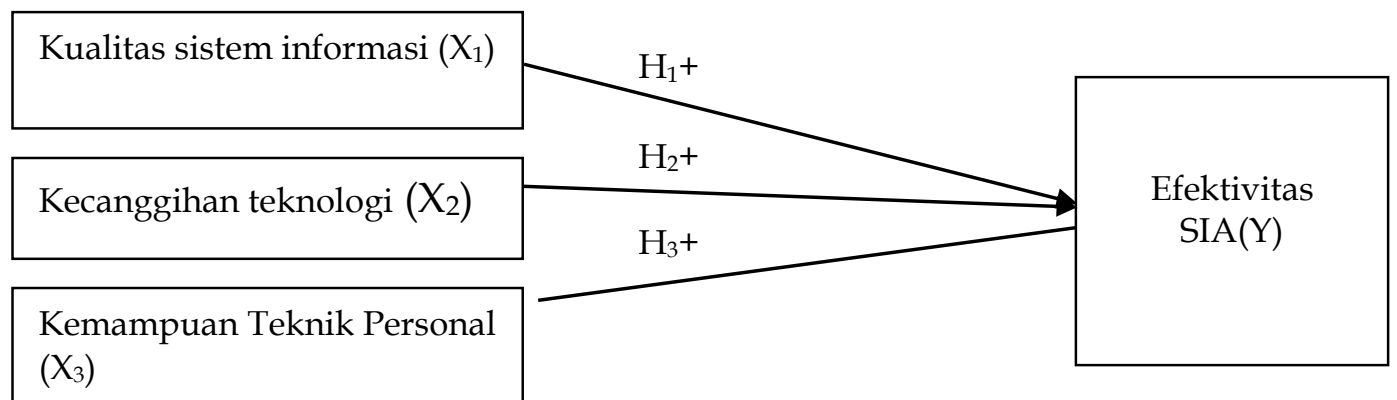

Sumber: Data Penelitian, 2019

\section{Gambar 1. Kerangka Konseptual}

Pada peneliti sebelumnya, penelitian yang dilakukan oleh Isti (2016). Yang menggunakan variabel bebas kualitas sistem informasi akuntansi menyimpulkan bahwa kualitas sistem informasi akuntansi berpengaruh positif terhadap kepuasaan pengguna. Hasil penelitian Sri (2016) bahwa kualitas sitem informasi berpengaruh positif pada kepuasaan pengguna akhir software akuntansi. Hasil penelitian Richard (2017) menyimpulkan bahwa kualitas sistem informasi akuntansi berpengaruh positif pada efektifitas sistem informasi akuntansi.

Kualitas sistem informasi menjadi faktor yang perlu diperhatikan, hal ini dikarenakan semakin bagus sistem informasi yang ada dalam sebuah organisasi akan berpengaruh pada meningkatnya efektivitas sistem informasi akuntansi. Sistem informasi Akuntansi yang berkualitas akan berpengaruh pada kemajuan organisasi. Berdasarkan uraian di atas dapat dirumuskan hipotesis sebagai berikut:

$\mathrm{H}_{1:}$ Kualitas sistem informasi berpengaruh positif pada efektivitas SIA.

Hubungan yang dapat dilihat dari kecanggihan teknologi informasi dengan efektifitas sistem informasi dijelaskan dengan pemikiran bahwa sistem yang memiliki kecanggihan teknologi informasi yang canggih akan membawa implikasi yang baik bagi efektifitas sistem infromasi akuntansi. Penelitian Dwitrayani (2012) dan Ratnaningsih (2014) yang menyimpulkan bahwa kecanggihan teknologi informasi berpengaruh positif dan signifikan terhadap efektivitas sistem informasi akuntansi.

Menurut Widarno (2008) menyatakan bahwa kecanggihan teknologi perlu dipertimbangkan dalam perencanaan dan pengembangan sistem infromasi akuntansi. Tingkat kecanggihan teknologi yang baik dapat menghasilkan informasi yang cepat dan akurat sehingga akan memengaruhi kualitas 
keputusan akhir sebagai alat untuk pengambilan keputusan oleh pihak manajemen. Dwitrayani (2012) menemukan pengaruh signifikan antara kecanggihan teknologi informasi dengan efektifitas sistem informasi akuntansi. Berdasarkan hal tersebut dapat dirumuskan hipotesis sebagai berikut:

$\mathrm{H}_{2}$ : Kecanggihan teknologi berpengaruh positif pada efektivitas SIA.

Personal yang memiliki kemampuan teknik penggunaan SIA dapat memahami manfaat yang diperoleh dari penggunaan SIA dan personal dapat lebih mudah dalam penggunannya. Berdasarkan hal tersebut menunjukkan bahwa semakin baik kemampuan teknik personal terhadap SIA maka semakin efektif penggunaan SIA tersebut. Penelitian yang dilakukan oleh Abhimantra, et. al.(2016) menyimpulkan bahwa kemampuan teknik personal berpengaruh pada kinerja sistem informasi akuntansi pada BPR di Kota Denpasar

Kinerja SIA dan kualitas SIA yang semakin meningkat dapat menghasilkan informasi yang berkualitas. Informasi yang berkualitas menunjukkan bahwa telah efektifnya penggunaan SIA. Penelitian yang dilakukan oleh Adisanjaya, et. al. (2017) menyimpulkan bahwa terdapat pengaruh positif dan signifikan antara kemampuan teknik personal terhadap efetivitas sistem informasi akuntasi. Berdasarkan pada uraian di atas maka dapat dirumuskan hipotesis sebagai berikut:

$\mathrm{H}_{3}$ : Kemampuan teknik personal berpengaruh positif pada efektivitas SIA.

\section{METODE PENELITIAN}

Pendekatan yang digunakan dalam penelitian ini berbentuk penelitian asosiatif dengan hubungan kausal apabila dilihat dari tingkat eksplanasinya. Penelitian asosiatif dengan hubungan kausal merupakan penelitian yang menjelaskan hubungan sebab akibat antara variabel satu dengan variabel lainnya (Sugiyono, 2017: 56). Penelitian ini dilaksanakan pada LPD di Kecamatan Tegallalang. Objek penelitian ini adalah pencegahan fraud pengelolaan dana desa yang ada di Kota Denpasar.

Variabel terikat pada penelitian ini adalah efektivitas SIA. Variabel ini digunakan karena SIA yang efektif dapat meningkatkan kualitas laporan keuangan sehingga pengambilan keputusan akan berlangsung efektif (Sajady 2008). Berdasarkan hal tersebut penting untuk mengetahui faktor-faktor yang memengaruhinya agar suatu organisasi dapat memiliki SIA yang efektif sehingga dapat meningkatkan kinerja karyawan dan organisasi tersebut. Variabel bebas digunakan dalam penelitian terdiri dari tiga variabel, yaitu kualitas sistem informasi $\left(X_{1}\right)$, kecanggihan teknologi $\left(X_{2}\right)$ dan kemampuan teknik personal $\left(X_{3}\right)$. Untuk mengetahui pengaruh kompetensi aparatur desa dan sistem pengendalian internal pada pencegahan fraud dengan internal locus of control sebagai variabel pemoderasi.

Jenis data dalam penelitian ini adalah data kuantitatif dan data kualitatif. Data kuantitatif dalam penelitian ini adalah skor dari jawaban kuesioner. Data kualitatif dalam penelitian ini adalah gambaran umum LPD, struktur organisasi LPD dan daftar nama LPD di Kecamatan Tegallalang. Data primer, yaitu data yang diperoleh langsung dari sumber asli tanpa melalui media perantara (Nur Indriantoro dan Supomo, 2013: 146). Data sekunder, yaitu data yang diperoleh secara tidak langsung oleh peneliti atau merupakan data yang bersumber dari 
pihak lain atau media perantara (Nur Indriantoro \& Supomo, 2013:147). Data sekunder dalam penelitian ini berupa informasi mengenai daftar nama LPD dan laporan keuangan LPD. Populasi dalam penelitian ini adalah seluruh LPD seKecamatan Tegallalang yaitu 45 LPD, data tersebut bersumber dari LPLPD Kabupaten Gianyar. Pengambilan sampel berarti mengambil sebagian dari populasi untuk menggambarkan sifat populasi yang bersangkutan dan harus representatif.

Teknik penentuan sampel yang digunakan dalam penelitian ini adalah non probability sampling, yaitu teknik pengambilan sampel yang tidak memberi peluang atau kesempatan sama bagi setiap unsur atau populasi untuk dipilih menjadi sampel. Bagian dari teknik non probability sampling yang digunakan dalam penelitian ini adalah metode purposive sampling. Adapun kriteria sampel dalam penelitian ini adalah LPD di Kecamatan Tegallalang yang menggunakan SIA dengan program aplikasi dalam pengolahan data. Kriteria sampel ini digunakan agar LPD yang terpilih menjadi sampel adalah LPD yang telah menerapkan SIA dengan program aplikasi.

Responden dalam penelitian ini adalah karyawan terlibat secara langsung dengan penggunaan sistem informasi akuntansi berbasis komputer yaitu kepala LPD, bendahara, dan bagian tata usaha. Hal ini bertujuan untuk memeroleh jawaban yang mampu memberikan pandangan mengenai kinerja SIA yang dioperasikan ke tempatnya bekerja. Jumlah kuisioner yang disebarkan di setiap LPD berjumlah kira-kira 3 kuisioner. Metode pengumpulan data dalam penelitian ini yaitu dengan teknik pengumpulan kuesioner. Jadi jumlah responden yang didapat dengan menerapkan kriteria tersebut berjumlah 48 orang yang diperoleh dari 16 sampel LPD yang telah menggunakan SIA berbasis aplikasi komputer.

Analisis linear berganda digunakan untuk mengetahui atau memperoleh gambaran mengenai pengaruh beberapa variabel independen pada variabel dependen secara bersama-sama. Analisis regresi linear berganda digunakan untuk mengetahui pengaruh kualitas sistem informasi Akuntansi, kecanggihan teknologi dan kemampuan teknik personal pada efektivitas SIA. Adapun persamaan regresi yang dihasilkan dari model regresi linear berganda dalam penelitian ini, yaitu:

$\mathrm{Y}=\mathrm{a}+\mathrm{B}_{1} \mathrm{X}_{1}+\mathrm{B}_{2} \mathrm{X}_{2}+\mathrm{B}_{3} \mathrm{X}_{3}+\mathrm{e}$.

Keterangan :

$\begin{array}{ll}\mathrm{Y} & : \text { Efektivitas SIA } \\ \mathrm{X}_{1} & : \text { Kualitas sistem informasi } \\ \mathrm{X}_{2} & : \text { Kecanggihan teknologi } \\ \mathrm{X}_{3} & : \text { Kemampuan teknik personal } \\ \mathrm{a} & : \text { Konstanta } \\ \mathrm{B}_{1}-\mathrm{B}_{3} & : \text { Koefisien regresi } \\ \mathrm{e} & : \text { Standar eror }\end{array}$

\section{HASIL DAN PEMBAHASAN}

Penelitian ini dilakukan untuk mengetahui pengaruh Kualitas Sistem Informasi Akuntansi, Kcanggihan Teknologi, dan Kemampuan Teknik Personal pada Efektivitas SIA di LPD Kecamatan Tegallalang. Responden yang digunakan 
dalam penelitian ini sebanyak 3 orang di masing-masing LPD yang tersebar di Kecamatan Tegallalang yaitu Kepala LPD, Bendahara dan Tata usaha LPD, Jumlah responden yang digunakan seluruhnya adalah 48 orang. Data penelitian ini diperoleh dengan mengumpulkan dan menyebarkan kuesioner ke 16 LPD di Kecamatan Tegallalang. Rincian mengenai pengiriman dan pengembalian kuesioner dapat dilihat pada Tabel 1 berikut.

Tabel 1. Rincian Pengiriman dan Pengembalian Kuesioner

\begin{tabular}{lc}
\hline \multicolumn{1}{c}{ Keterangan } & Jumlah Kuesioner \\
\hline Kuesioner yang diantar langsung & 48 \\
Kuesioner yang tidak dikembalikan & $(0)$ \\
Kuesioner yang kembali & 48 \\
Kuesioner yang digugurkan & $(0)$ \\
Kuesioner yang digunakan & 48 \\
Tingkat pengembalian kuesioner (respon rate) & $48 / 48 \times 100 \%=100 \%$ \\
Tingkat pengembalian yang digunakan (usable respon & $48 / 48 \times 100 \%=100 \%$ \\
rate)
\end{tabular}

Sumber : Data Penelitian, 2019

Berdasarkan Tabel 1. yang menunjukkan bahwa dari 48 kuesioner yang tersebar, keseluruhannya kembali dengan pengisian yang lengkap dan memenuhi ketentuan sehingga tidak ada kuesioner yang gugur, hasil ini didapatkan karena peneliti mendampingi secara langsung pada saat pengisian kuesioner. Perhitungan dari data tersebut menghasilkan response rate $100 \%$ dengan usable response rate sebesar $100 \%$.

Berdasarkan profil dari 48 responden yang mengisi kuesioner pada penelitian ini, diperoleh karakteristik jenis kelamin responden, terdiri atas dua kelompok, yaitu kelompok laki-laki dan perempuan. Hasil analisis data ditunjukkan pada Tabel 2. berikut:

Tabel 2. Karakteristik Responden Berdasarkan Jenis Kelamin

\begin{tabular}{llll}
\hline No & Jenis Kelamin & Jumlah & Persentase (\%) \\
\hline 1. & Laki-laki & 36 & $75 \%$ \\
2. & Perempuan & 12 & $25 \%$ \\
& Jumlah & 48 & $100 \%$ \\
\hline
\end{tabular}

Sumber : Data Penelitian, 2019

Berdasarkan Tabel 2. dapat dilihat dari 48 responden yang diambil sebagai sampel, menunjukkan bahwa jumlah Pegawai LPD dengan jenis kelamin lakilaki berjumlah 36 orang atau sebesar $75 \%$ dan jenis kelamin perempuan 12 orang atau sebesar $25 \%$. Hal ini menunjukkan bahwa jumlah pegawai LPD berjenis kelamin laki-laki lebih banyak daripada pegawai berjenis kelamin perempuan.

Berdasarkan umur responden, terdiri atas beberapa kelompok, yaitu 20-35, 36-50, >50 tahun. Hasil analisis data ditunjukkan pada tabel 3. berikut:

Tabel 3. Karakteristik Responden Berdasarkan umur

\begin{tabular}{llll}
\hline No & Umur & Jumlah & Persentase $(\%)$ \\
\hline 1. & $20-35$ & 8 & $16,66 \%$ \\
2. & $36-50$ & 35 & $72,91 \%$ \\
3. & $>50$ & 5 & $10,41 \%$ \\
& Jumlah & 48 & $100 \%$ \\
\hline
\end{tabular}

Sumber : Data Penelitian, 2019 
Pegawai LPD dengan umur 20-35 tahun sebanyak 8 orang atau setara dengan $16,66 \%$, pegawai LPD dengan umur 36-50 sebanyak 35 orang dengan presentase $72,91 \%$, dan pegawai LPD dengan umur $>50$ sebanyak 5 orang dengan presentase $10,41 \%$. Dapat disimpulkan bahwa pegawai LPD paling banyak berumur 36-50 tahun.

Berdasarkan lama bekerja responden, terdiri atas tiga kelompok, yaitu 1-5 tahun, 6-10 tahun, dan >10 tahun. Hasil analisis data ditunjukkan pada tabel 4 . berikut:

Tabel 4. Karakteristik Responden Berdasarkan Lama Bekerja

\begin{tabular}{llll}
\hline No & Lama bekerja (tahun) & Jumlah & Persentase $(\%)$ \\
\hline 1. & $1-5$ & 3 & $6,25 \%$ \\
2. & $6-10$ & 7 & $14,58 \%$ \\
3. & $>10 \quad$ Jumlah & 38 & $79,16 \%$ \\
& & 48 & $100 \%$ \\
\hline
\end{tabular}

Sumber: Data Penelitian, 2019

Pegawai LPD dengan lama bekerja selama 1 sampai 5 tahun sebanyak 3 orang atau sebesar 6,25 persen, kemudian pegawai LPD dengan lama bekerja selama 6 sampai 10 tahun sebanyak 7 orang atau sebesar 14,58 persen dan pegawai LPD dengan lama bekerja lebih dari 10 tahun sebanyak 38 orang atau sebesar 79,16 persen. Pegawai LPD sebagian besar sudah bekerja selama lebih dari 10 tahun yaitu sebanyak 38 orang pegawai.

Tabel 5. Statistik Deskriptif

\begin{tabular}{lccccc}
\hline \multicolumn{1}{c}{ Variabel } & N & Min. & Max. & Mean & $\begin{array}{c}\text { Std. } \\
\text { Deviation }\end{array}$ \\
\hline Kualitas SIA & 48 & 13.00 & 20.00 & 17.1458 & 2.2407 \\
Kecanggihan Teknologi & 48 & 15.00 & 24.00 & 19.9167 & 2,2392 \\
Kemampuan Teknik & 48 & 12.00 & 24.00 & 18,4792 & 3,6494 \\
Personal & & & & & \\
Efektivitas SIA & 48 & 23.00 & 32.00 & 27,5833 & 3,0999 \\
Valid N (listwise) & 48 & & & & \\
\hline
\end{tabular}

Sumber : Data Penelitian, 2019

Kualitas SIA $\left(X_{1}\right)$ memiliki nilai terendah 13.00, nilai tertinggi 20.00, nilai rata-rata 17.1458 dan standar deviasinya 2.2407. Hal ini menunjukkan bahwa standar penyimpangan terhadap nilai rata-ratanya adalah 2.2407. Nilai rata-rata 17.1458 menunjukkan secara rata-rata jawaban responden cenderung mengarah ke nilai maksimal, yang artinya sebagian besar responden cenderung mengarah ke nilai tertinggi yang artinya persepsi responden tentang Kualitas SIA yang digunakan cenderung tinggi.

Kecanggihan Teknologi $\left(X_{2}\right)$ memiliki nilai terendah 15.00, nilai tertinggi 24.00, nilai rata-rata 19,9167 dan standar deviasinya 2,2392. Hal ini menunjukkan bahwa standar penyimpangan terhadap nilai rata-ratanya adalah2,2392. Nilai rata-rata 19,9167 menunjukkan secara rata-rata jawabn responden cenderung mengarah ke nilai maksimal yang artinya persepsi individu tentang kecanggihan teknologi yang digunakan cenderung tinggi.

Kemampuan Teknik Personal $\left(X_{3}\right)$ memiliki nilai terendah 12.00, nilai tertinggi 24.00, nilai rata-rata 18,4792 dan standar deviasinya 3,6494. Hal ini menunjukkan bahwa standar penyimpangan terhadap nilai rata-ratanya 
adalah3,6494. Nilai rata-rata 18,4792 menunjukkan secara rata-rata jawaban responden cenderung mengarah ke nilai tertinggi yang artinya persepsi responden tentang kemampuan teknik personal pada efektivitas SIA cenderung tinggi. Efektivitas Sistem Informasi Akuntansi $\left(X_{4}\right)$ memiliki nilai terendah 23.00, nilai tertinggi 32.00, nilai rata-rata 27,5833 dan standar deviasinya 3,0999. Hal ini menunjukkan bahwa standar penyimpangan terhadap nilai rata-ratanya adalah 3,0999 . Nilai rata-rata 27,5833 menunjukkan secara rata-rata jawaban responden cenderung mengarah ke nilai tertinggi yang artinya persepsi responden tentang Efektivitas SIA cenderung tinggi.

Hasil uji validitas pada Tabel 6. menunjukkan bahwa seluruh instrumen penelitian yang digunakan untuk mengukur variabel kualitas sistem informasi, kecanggihan teknologi, kemampuan teknik personal dan efektivitas SIA memiliki nilai koefisien korelasi dengan skor total seluruh item pernyataan lebih besar dari 0,30 dengan signifikansi kurang dari 0,05. Hal ini menunjukkan bahwa butir-butir pernyataan dalam instrument penelitian tersebut valid dan layak digunakan sebagai instrument penelitian

\section{Tabel 6. Rekapitulasi Hasil Uji Validitas Instrumen Penelitian}

\begin{tabular}{ccccc}
\hline Variabel & Indikator & Koefisien Korelasi & Sig. (2-tailed) & Keterangan \\
\hline & $\mathrm{X}_{1.1}$ & 0,878 & 0,000 & Valid \\
Kualitas sistem & $\mathrm{X}_{1.2}$ & 0,831 & 0,000 & Valid \\
informasi $\left(\mathrm{X}_{1}\right)$ & $\mathrm{X}_{1.3}$ & 0,898 & 0,000 & Valid \\
& $\mathrm{X}_{1.4}$ & 0,798 & 0,000 & Valid \\
& $\mathrm{X}_{1.5}$ & 0,600 & 0,000 & Valid \\
& $\mathrm{X}_{2.1}$ & 0,703 & 0,000 & Valid \\
& $\mathrm{X}_{2.2}$ & 0,790 & 0,000 & Valid \\
Kecanggihan & $\mathrm{X}_{2.3}$ & 0,703 & 0,000 & Valid \\
teknologi $\left(\mathrm{X}_{2}\right)$ & $\mathrm{X}_{2.4}$ & 0,719 & 0,000 & Valid \\
& $\mathrm{X}_{2.5}$ & 0,491 & 0,000 & Valid \\
& $\mathrm{X}_{2.6}$ & 0,762 & 0,000 & Valid \\
& $\mathrm{X}_{3.1}$ & 0,914 & 0,000 & Valid \\
& $\mathrm{X}_{3.2}$ & 0,946 & 0,000 & Valid \\
Kemampuan teknik & $\mathrm{X}_{3.3}$ & 0,873 & 0,000 & Valid \\
personal $\left(\mathrm{X}_{3}\right)$ & $\mathrm{X}_{3.4}$ & 0,850 & 0,000 & Valid \\
& $\mathrm{X}_{3.5}$ & 0,863 & 0,000 & Valid \\
& $\mathrm{X}_{3.6}$ & 0,681 & 0,000 & Valid \\
& $\mathrm{Y}_{1}$ & 0,786 & 0,000 & Valid \\
& $\mathrm{Y}_{2}$ & 0,771 & 0,000 & Valid \\
& $\mathrm{Y}_{3}$ & 0,753 & 0,000 & Valid \\
& $\mathrm{Y}_{4}$ & 0,731 & 0,000 & Valid \\
& $\mathrm{Y}_{5}$ & 0,716 & 0,000 & Valid \\
& $\mathrm{Y}_{6}$ & 0,855 & 0,000 & Valid \\
& $\mathrm{Y}_{7}$ & 0,656 & 0,000 & Valid \\
& $\mathrm{Y}_{8}$ & 0,659 & 0,000 & Valid \\
\hline
\end{tabular}

Sumber : Data Penelitian, 2019 
Uji Reliabilitas terhadap instrumen penelitian ini menggunakan nilai Alpha Cronbach. Nilai Alpha Cronbach dinyatakan reliabel jika nilainya lebih besar atau sama dengan 0,60 .

\section{Tabel 7. Rekapitulasi Hasil Uji Reliabilitas Instrumen Penelitian}

\begin{tabular}{clcc}
\hline No. & \multicolumn{1}{c}{ Variabel } & Cronbach's Alpha & Keterangan \\
\hline 1 & Kualitas sistem informasi $\left(\mathrm{X}_{1}\right)$ & 0,807 & Reliabel \\
2 & Kecanggihan teknologi $\left(\mathrm{X}_{2}\right)$ & 0,775 & Reliabel \\
3 & Kemampuan teknik personal $\left(\mathrm{X}_{3}\right)$ & 0,809 & Reliabel \\
4 & Efektivitas SIA $(\mathrm{Y})$ & 0,779 & Reliabel \\
\hline
\end{tabular}

Sumber : Data Penelitian, 2019

Hasil uji reliabilitas yang disajikan dalam Tabel 7. menunjukkan bahwa seluruh instrumen penelitian memiliki koefisien Cronbach's Alpha lebih dari 0,60. Jadi dapat dinyatakan bahwa seluruh variabel telah memenuhi syarat reliabilitas atau kehandalan sehingga dapat digunakan untuk melakukan penelitian.

Tabel 8. Hasil Uji Normalitas

\begin{tabular}{lc}
\hline & Unstandardized Residual \\
\hline $\mathrm{N}$ & 48 \\
Kolmogorov-Smirnov Z & 0,582 \\
Asymp. Sig. (2-tailed) & 0,887 \\
\hline
\end{tabular}

Sumber : Data Penelitian, 2019

Berdasarkan hasil analisis pada TabeL 8. didapat nilai signifikansi sebesar 0,887 yang lebih dari 0,05 maka dapat disimpulkan bahwa model persamaan regresi dalam penelitian ini sudah berdistribusi normal.

\section{Tabel 9. Hasil Uji Multikoleniaritas}

\begin{tabular}{lccc}
\hline \multicolumn{1}{c}{ Variabel } & Tolerance & VIF & Keterangan \\
\hline Kualitas sistem informasi $\left(\mathrm{X}_{1}\right)$ & 0,523 & 1,912 & Bebas multikol \\
Kecanggihan teknologi $\left(\mathrm{X}_{2}\right)$ & 0,406 & 2,463 & Bebas multikol \\
Kemampuan teknik personal $\left(\mathrm{X}_{3}\right)$ & 0,673 & 1,486 & Bebas multikol \\
\hline
\end{tabular}

Sumber: Data Penelitian, 2019

Berdasarkan Tabel 9. dapat dilihat bahwa nilai tolerance dan VIF dari seluruh variabel bebas yang diuji yaitu kualitas sistem informasi, kecanggihan teknologi, dan kemampuan teknik personal menunjukkan bahwa nilai tolerance untuk setiap variabel lebih besar dari 10\% dan nilai VIF lebih kecil dari 10 yang berarti model persamaan regresi bebas dari multikolinearitas.

Tabel 10. Hasil Uji Heteroskedastisitas

\begin{tabular}{|c|c|c|c|c|c|}
\hline \multirow[t]{3}{*}{ Model } & \multicolumn{2}{|c|}{$\begin{array}{l}\text { Unstandardized } \\
\text { Coefficients }\end{array}$} & \multirow{3}{*}{$\begin{array}{c}\text { Standardized } \\
\text { Coefficients }\end{array}$} & \multirow[b]{3}{*}{$\mathrm{t}$} & \multirow[b]{3}{*}{ Sig. } \\
\hline & & & & & \\
\hline & $\mathrm{B}$ & Error & & & \\
\hline 1 (Constant) & 3.994 & 1.246 & & 3.204 & .003 \\
\hline Kualitas sistem informasi & .014 & .084 & .033 & .168 & .867 \\
\hline Kecanggihan teknologi & -.122 & .095 & -.284 & -1.286 & .205 \\
\hline $\begin{array}{l}\text { Kemampuan teknik } \\
\text { personal }\end{array}$ & -.037 & .045 & -.138 & -.807 & .424 \\
\hline
\end{tabular}

Sumber : Data Penelitian, 2019

Pada Tabel 10 dapat dilihat bahwa nilai signifikansi dari variabel kualitas sistem informasi sebesar 0,867, nilai signifikansi variabel kecanggihan teknologi sebesar 0,205, dan kemampuan teknik personal sebesar 0,424. Nilai tersebut lebih besar dari 0,05 yang berarti tidak terdapat pengaruh antara variabel bebas 
terhadap absolute residual. Dengan demikian, model yang dibuat tidak mengandung gejala heteroskedastisitas.

Tabel 11. Hasil Analisis Regresi Linier Berganda

\begin{tabular}{lccccc}
\hline \multicolumn{1}{c}{ Variabel } & \multicolumn{2}{c}{$\begin{array}{c}\text { Unstandardized } \\
\text { Coefficients }\end{array}$} & $\begin{array}{c}\text { Standardized } \\
\text { Coefficients }\end{array}$ & thitung & $\begin{array}{c}\text { Sig. } \\
\text { uji t }\end{array}$ \\
\cline { 2 - 4 } & $\mathrm{B}$ & Std. Error & Beta & & \\
\hline (Constant) & 3,832 & 2,067 & & 1,854 & 0,070 \\
Kualitas sistem & 0,714 & 0,139 & 0,516 & 5,144 & 0,000 \\
informasi & & & & & \\
Kecanggihan teknologi & 0,389 & 0,158 & 0,281 & 2,471 & 0,017 \\
Kemampuan teknik & 0,204 & 0,075 & 0,240 & 2,711 & 0,010 \\
$\quad \begin{array}{l}\text { personal } \\
\text { R Square }\end{array}$ & 0,769 & & & & \\
Adjusted R Square & 0,753 & & & & \\
F Statistik & 48,710 & & & & \\
Signifikansi Uji F & 0,000 & & & &
\end{tabular}

Berdasarkan hasil analisis regresi linier berganda seperti yang disajikan pada Tabel 11, maka dapat dibuat persamaan regresi sebagai berikut:

$$
Y=3,832+0,714 X_{1}+0,389 X_{2}+0,204 X_{3}+\varepsilon
$$

Tabel 11. menunjukkan koefisien regresi pada masing-masing variabel bebas yang diuji memiliki arah koefisien yang positif dan memiliki nilai signifikansi kurang dari 0,05. Hal ini menunjukkan bahwa seluruh variabel bebas dalam penelitian ini memiliki pengaruh yang positif dan signifikan pada variabel efektivitas SIA.

Besarnya pengaruh variabel bebas terhadap variabel terikat ditunjukkan oleh nilai determinasi total (Adjusted R Square). Hasil uji koefisien determinasi pada Tabel 11 menunjukkan nilai Adjusted R Square sebesar 0,753 mempunyai arti bahwa sebesar $75,3 \%$ variasi efektivitas SIA pada LPD di Kecamatan Tegallalang dipengaruhi oleh variasi kualitas sistem informasi, kecanggihan teknologi, dan kemampuan teknik personal, sedangkan sisanya sebesar 24,7\% dijelaskan oleh faktor lain yang tidak dimasukkan ke dalam model.

Hasil pengolahan data pada tabel 11 dengan menggunakan program SPSS

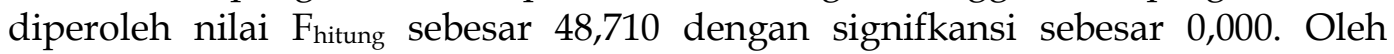

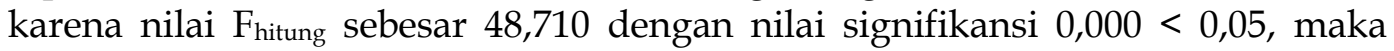
dapat disimpulkan bahwa pada kelompok yang diuji memiliki perbedaan yang nyata (signifikan). Hasil ini mempunyai arti bahwa secara simultan kualitas sistem informasi, kecanggihan teknologi, dan kemampuan teknik personal berpengaruh signifikan terhadap efektivitas SIA pada LPD di Kecamatan Tegallalang.

Berdasarkan hasil perhitungan yang ditujukan pada Tabel 11 diketahui bahwa nilai $\beta_{1}=0,714$ dengan tingkat signifikansi t uji satu sisi sebesar 0,000 yang berarti lebih kecil dari nilai $a=0,05$. Hal ini menunjukkan bahwa variabel kualitas SIA berpengaruh positif signifikan pada Efektivitas Sistem Informasi Akuntansi. Hipotesis pertama $\left(\mathrm{H}_{1}\right)$ yaitu kualitas SIA berpengaruh positif pada Efektivitas Sistem Informasi Akuntansi diterima. 
Sistem informasi yang berkualitas yaitu sistem yang fleksibel, efisien, dapat diakses dan tepat waktu. Hasil kuesioner menunjukkan item pernyataan keempat yaitu sistem yang disediakan bersifat fleksibel mendapat skor tertinggi. Hal ini menunjukkan SIA yang digunakan adalah SIA yang berkualitas sehingga akan dapat meningkatkan efetivitas SIA pada LPD tersebut. Sedangkan item pernyataan ketiga yaitu sistem yang disediakan dapat diandalkan mendapatkan skor terendah, hal ini menunjukkan bahwa masih ada pihak-pihak yang menganggap bahwa menggunakan sistem secara manual akan lebih efektif dibandingkan menggunakan sistem secara terkomputerisasi, juga dapat dilihat dari lama bekerja pegawai bahwa mayoritas pegawai telah bekerja lebih dari 10 tahun yang membuktikan bahwa beberapa pegawai LPD perlu menyesuaikan diri dalam penggunaan sistem manual ke sistem terkomputerisasi.

Hasil penelitian membuktikan bahwa kualitas SIA mampu mngefektifkan penggunaan SIA untuk karyawan LPD di Kecamatan Tegallalang. Berdasarkan hal tersebut menunjukkan bahwa semakin tinggi tingkat kualitas SIA pada LPD Kecamatan Tegallalang maka efektivitas SIA akan semakin meningkat, sebaliknya semakin rendah kualitas SIA pada LPD Kecamatan Tegallalang maka efektivitas SIA akan semakin menurun. Hal ini sesuai dengan teori TAM yaitu ketika SIA berkualitas maka SIA tersebut akan memberikan kemudahan dan manfaat yang dapat meningkatkan efektvitas sistem informasi akuntansi.

Hasil penelitian ini juga sesuai dengan penelitian yang dilakukan oleh Isti (2016) yang menggunakan variabel bebas kualitas sistem informasi akuntansi menyimpulkan bahwa kualitas sistem informasi akuntansi berpengaruh positif terhadap kepuasaan pengguna. Begitu halnya dengan hasil penelitian Sri (2016) bahwa kualitas sitem informasi berpengaruh positif pada kepuasaan pengguna akhir software akuntansi.

Berdasarkan hasil perhitungan yang ditunjukkan pada Tabel 11 diketahui bahwa nilai $\beta_{2}=0,389$ dengan tingkat signifikansi t uji satu sisi sebesar 0,017 yang berarti lebih kecil dari nilai $a=0,05$. Hal ini menunjukkan bahwa variabel kecanggihan teknologi berpengaruh positif signifikan pada efektivitas SIA. Hasil hipotesis kedua $\left(\mathrm{H}_{2}\right)$ yaitu kecanggihan teknologi berpengaruh positif pada efektivitas SIA diterima.

Hasil kuesioner menunjukkan bahwa item pernyataan kelima yaitu software akuntansi yang digunakan di tempat saya bekerja meningkatkan kinerja perusahaan mendapatkan skor tertinggi. Ini menunjukkan bahwa dengan adanya SIA yang canggih akan dapat meningkatkan minat personal untuk menggunakan SIA sehingga efektivitas SIA akan meningkat. Item pernyataan pertama, yaitu sistem informasi terkomputerisasi yang digunakan di tempat saya bekerja sudah didukung oleh fasilitas perangkat keras dan spesifikasi yang canggih mendapatkan skor terendah. Hal ini menjelaskan bahwa masih terdapat beberapa pihak yang menganggap SIA yang diterapkan ditempatnya bekerja belum didukung oleh perangkat keras dengan spesifikasi yang canggih.

Hubungan yang dapat dilihat dari kecanggihan teknologi informasi dengan efektifitas sistem informasi akuntansi menurut teori TAM dijelaskan dengan pemikiran bahwa sistem yang memiliki kecanggihan teknologi informasi yang canggih akan membawa implikasi yang baik bagi efektifitas sistem infromasi akuntansi. Penelitian Dwitrayani (2012) dan Ratnaningsih (2014) yang 
menyimpulkan bahwa kecanggihan teknologi informasi berpengaruh positif dan signifikan terhadap efektivitas sistem informasi akuntansi.

Berdasarkan hasil perhitungan yang ditunjukkan pada Tabel 11 diketahui bahwa nilai $\beta_{3}=0,204$ dengan tingkat signifikansi t uji satu sisi sebesar 0,010 yang berarti lebih kecil dari nilai $a=0,05$. Hal ini menunjukkan bahwa variabel kemampuan teknik personal berpengaruh positif pada efektivitas penggunaan SIA. Hipotesis ketiga $\left(\mathrm{H}_{3}\right)$ yaitu kemampuan teknik personal berpengaruh positif pada efektivitas penggunaan SIA diterima.

Hasil penelitian ini sesuai teori TAM yaitu kemanfaatan dan kemudahan penggunaan akan mempengaruhi persepsi personal untuk menerima dan menggunakan teknologi, dimana personal yang mampu mengoperasikan SIA berbasis komputer akan mendapatkan kemudahan dalam penggunaannya sehingga personal tersebut akan terus menggunakan SIA berbasis aplikasi komputer. Hasil penelitian ininjuga sejalan dengan penelitian yang dilakukan oleh Abhimantra, et. al.(2016) menyimpulkan bahwa kemampuan teknik personal berpengaruh pada kinerja sistem informasi akuntansi pada BPR di Kota Denpasar. Penelitian yang dilakukan oleh Adisanjaya, et. al. (2017) juga menyimpulkan bahwa kemampuan teknik personal berpengaruh positif pada efektivitas sistem informasi akuntansi.

\section{SIMPULAN}

Tujuan penelitian ini menjelaskan bagaimana ketiga faktor yakni kualitas SIA, kecanggihan teknologi, dan kemampuan teknik personal pada efektivitas SIA. Sehingga, hasil yang dapat diperoleh penelitian ini adalah kualitas SIA berpengaruh positif pada efektivitas SIA. Hal ini menjelaskan bahwa kualitas SIA yang merepresentasikan kegunaan dalam teori TAM akan mampu meningkatkan penerimaan personal terhadap suatu sistem yang kemudian akan meningkatkan efektivitas SIA. Kecanggihan teknologi berpengaruh positif pada efektivitas SIA. Hal ini sesuai dengan teori TAM bahwa dengan adanya kemudahan yang ditimbulkan dari kecanggihan teknologi tersebut akan mampu meningkatka minat personal untuk menggunakan SIA sehingga efektivitas SIA di LPD Kecamatan Tegallalang meningkat. Kemampuan teknik personal berpengaruh positif pada efektivitas SIA. Hal ini menjelaskan bahwa dengan adanya kemampuan yang dimiliki masing-masing pegawai LPD di Kecamatan Tegallalang akan sangat mampu meningkatkan efektivitas SIA yang diterapkan di LPD tersebut.

Berdasarkan hasil penelitian diatas, saran yang bisa disampaikan kepada pihak LPD yaitu meningkatkan pelatihan penggunaan sistem informasi akuntansi sehingga keterampilan pegawai dalam menggunakan sistem menjadi lebih baik sehingga para pegawai dapat lebih cepat dalam menyelesaikan pekerjaannya. Penelitian selanjutnya diharapkan dapat diterapkan di lokasi yang berbeda dan menambahkan variabel moderasi maupun menambah variabel dengan referensi baru. 


\section{REFERENSI}

Abhimantra, Wayan Purwa dan I Ketut Suryanawa, (2016), "Analisis Faktorfaktor Yang Mempengaruhi Kinerja Sistem Informasi Akuntansi", ISSN:2302-8559 E-Jurnal Akuntansi Udayana.14.3, Hal.1782-1809.

Adisanjaya, Ari Wahyuni Made, Purnawati I Gusti Ayu, (2017), "Pengaruh Kemampuan Personal, Pelatihan dan Pendidikan serta Pemanfaatan Teknologi Terhadap Efektivitas Sistem Informasi Akuntansi Pada Mini Market Bali Mandara". E Jurnal Akuntansi Universitas Pendidikan Ganesha. Volume: 7 No: 1 Tahun 2017

Almilia, Luciana Spica dan Briliantien. (2007). Faktor-faktor yang Mempengaruhi Kinerja Sistem Informasi Akuntansi pada Bank Umum Pemerintah di Wilayah Surabaya dan Siduarjo. Jurnal Ilmiah. STIE Perbanas. Surabaya.

Alsarayreh M.N., Jawabreh O.A., Jaradat M.F., and Alamro S.A. (2011). Technological Impact on Effectiveness of Accounting Information System (AIS) Applied by Aqaba Tourist Hotels. European Journal of Scientific Research, 59(3), pp: 361-369.

A Hall, James.(2011).Sistem Informasi Akuntansi, Edisi 4, Jakarta:Salemba Empat

Choe, J.M., (1996)."The Relationship Among Performance of Accounting Information System, Influence Factors And Evolution Level Of Information System".Journal of Management Information System/Spring.Vol. 12 No. 4. PP 215-239.

Damana Agus Wahyu Arya, (2016), Pengaruh Keterlibatan Pemakai, Pelatihan, Ukuran Organisasi Dan Keahlian Pemakai Terhadap Kinerja Sistem Informasi Akuntansi. Jurnal Akuntansi. Universitas Udayana. Bali

Davis,F.D. (1989). "Perceived Usefulness, Perceived Ease of Use, and User Acceptance of Information Technology". MIS Quarterly.Vol. 13 No. 5: pp319-339.

DeLone, W. H., and McLean, E. R. (1992). Information Systems Success: The Quest for The Dependent Variable. Information Systems Research. 3(1). pp: 60-95.

DeLone, W. H., \& McLean, E. R. (2003). "The DeLone and McLean Model of Information Systems Success : A Ten-Year Update". Journal of Management Information Systems / Spring 2003, Vol. 19, No. 4, pp. 9-30.

Dharmawan, Joshua \& Ardianto, Jimmy. (2017). Pengaruh Kemutakhiran Teknologi, Kemampuan Teknik Personal Sistem Informasi, Program Pelatihan Pengguna Dan Dukungan Manajemen Puncak Terhadap Kinerja Sistem Informasi Akuntansi (Studi Empiris Pada Karyawan Perusahaan RetailConsumer Goods Wilayah Tangerang Dan Bintaro). Ultima Accounting, 9(1).

Dwinda Kharisma dan Ida Bagus Dharmadiaksa (2015) Pengaruh Keterlibatan Pengguna Dan Ukuran Organisasi Pada Efektivitas Penggunaan Sistem Informasi Akuntansi. E-Jurnal Akuntansi Universitas Udayana 10.3 (2015): 867-881 ISSN: 2302-8556

Dwitrayani, Made Christin. (2012). Pengaruh Kecanggihan TI dan Partisipasi Manajemen terhadap Efektivitas Sistem Informasi Akuntansi BPR di Kabupaten Badung. E-Jurnal Ekonomi dan Bisnis Universitas Udayana 6.1 (2017): 197-222 
Fung, Tjhai Jen. (2002).“Faktor-Faktor Yang Mempengaruhi Kinerja Sistem Informasi Akuntansi". Jurnal Bisnis dan Akuntansi.Vol. IV No. 2.

Galang Rahadian Prabowo, A. M. (2014). Faktor-Faktor yang Mempengaruhi Kinerja Sistem Informasi Akuntansi. Accounting Analysis Journal, 3(1), pp:19.

Granell, Ximo, (2014), Multilingual Information Management: Information, Technology, and Translators, Chandos Publishing, Oxford.

Hall, James. A. (2001). Sistem Informasi Akuntansi. Jakarta: Salemba Empat

Handoko Richard, Dharmadiaksa Ida Bagus. (2017). Faktor-faktor yang Memengaruhi Pada Efektivitas Sistem Informasi Akuntansi Hotel Berbintang Tiga di Denpasar. E-Jurnal Akuntansi Universitas Udayana. vol.21,No.2.

Hary Gustiyan. (2014). Analisis faktor-faktor yang mempengaruhi Kinerja sistem Informasi Akuntansi ada Bank Perkreditan Rakyat (BPR) di Tanjungpinang. Journal Jurusan Akuntansi Fakultas Ekonomi.Universitas Maritim Raja Ali Haji Tanjungpinang.

Havelka, Douglas. (2004). Students Beliefs and Attitudes Toward Technology. Informatioon Systems Education Journal. Vol 1 No. 40. December 27, 2003

Hendarti, Henny, dan Gui, A. (2008). Korelasi Antara Efektivitas Sistem Informasi Penjualan dengan Kinerja User. Seminar Nasional Aplikasi Teknologi Informasi 2008 (SNATI 2008) ISSN: 1907-5022. Yogyakarta.

Hussin, H., King. M. And Cragg, P.B. (2012). IT Alignment In Small Firms.European Journal Of Information Systems, 11 (1), Pp: 108-127.

Indriantoro, N., \& Supomo, B. (1999). Metodologi penelitian bisnis untuk akuntansi dan manajemen. BPFE

Ismail, N. A. (2009). Factors Influencing AIS Effectiveness Among Manufacturing SMEs: Evidence From Malaysia. Journal on Information Systems in Developing Countries, 38(10), pp: 1-19.

Isti, Nugraheni Saputri. (2016).Pengaruh Kualitas Sistem Informasi Akuntansi Terhadap Kepuasan Pengguna Paket Program Aplikasi Sistem Informasi Akuntansi (Studi Empiris pada Bank Perkreditan Rakyat Boyolali). Surakarta :Universitas Muhammadiyah Surakarta.

Kasandra, Ni Made Ayu dan Gede Juliarsa. (2016). Pengaruh Kualitas Penerapan SIA, Pemanfaatan Dan Kepercayaan Tteknologi Informasi Pada Kinerja Karyawan. E-Jurnal Akuntansi Universitas Udayana. Vol 14.1.

Komara, Acep. (2005)."Analisis Faktor-Faktor yang Mempengaruhi Kinerja Sistem informasi akuntansi”.Jurnal SNA 8. Halaman 836-848.

LP LPD Kabupaten Gianyar Tahun 2019.

Martha Suhardiyah dan R. Bambang Dwi Waryanto (2014), Analisis faktor-faktor yang mempengaruhi kinerja sistem informasi. Jurnal ekonomi. Universitas PGRI AdiBuana Surabaya.

McLeod, Raymond, Jr, Sistem Informasi Manajemen. Jilid I dan II, terjemahan oleh Hendra Teguh (1996), PT.Buana Ilmu Populer, Jakarta.

Meiryani. (2014). Influence User Involvement On The Quality of Accounting Information Systems.International Journal of Scientific \& Technology Research volume 3, issue 8, August 2014. ISSN 2277- 8616, page 118-124. 
Ogah, Idagu, Joseph, (2013), An Evaluation of the Relevance of Accounting Systems as a Management Decision Tool in Union Bank of Nigeria Plc, Uyo Branch of Akwa Ibom,Greener Journal of Business and Management Business Study, Vol. 3 (1), pp: 38-45.

Pemerintah Provinsi Bali. Peraturan Gubernur Bali Nomor 11 Tahun 2013 Tentang Petunjuk Pelaksanaan Peraturan Daerah Provinsi Bali Nomor 8 Tahun 2002 Tentang Lembaga Perkreditan Desa

Perbarini, Ni Kadek Ayu dan Juliarsa, Gede. (2014). Analisis Faktor-Faktor Yang Mempengaruhi Kinerja Sistem Informasi Akuntansi Pada Lpd Di Kecamatan Denpasar Utara.E-Jurnal Akuntansi Universitas Udayana, 9(3),pp:728-746.

Priyo Hari, Adi. (2006). Partisipasi Pengguna Dalam Pengembangan Sistem Informasi (Telaah Literatur). Jurnal Akuntansi dan Keuangan Universitas Kristen Petra.

Ratnaningsih., Suaryana. (2014). Pengaruh Kecanggihan Teknologi Informasi, Partisipasi, dan Pengetahuan Manajer Akuntansi pada Efektivitas Sistem Informasi Akuntansi. ISSN: 2302-8556 E-Jurnal Akuntansi Undayana 6.1 (2014):1-16.

Raymond, L. and Pare, G. (1992). Maesurment of information Tecnology Sophistication in Small Manufacturing Business, Information Resourses Manajement Journal ,Vol. 5 no.2. 2, pp 4-6.

Rini. (2010). Analisis Faktor-Faktor yang Mempengaruhi Minat Pemanfaatan Sistem Informasi dan Penggunaan Sistem Informasi.STIE Atma Bhakti Surakarta.

Romney, Marshall B., dan Paul John Steinbart, (2015). Accounting Information systems, $13^{\text {th }}$ ed. England: Pearson Educational Limited.

Sajady, Dastgir, M., \& Nejad, H. (2008). Evaluation of the Effectiveness of Accounting Information Systems. International Journal of Information Science \& Technology, 6(2), 49-59.

Sri Rukmiyati Ni Made dan I Ketut Budhiartha. (2016). Pengaruh Kualitas Informasi, Kualitas Informasi dan Perceived Usefulness Pada Kepuasan Pengguna Akhir Software Akuntansi (Studi Empiris Pada Hotel Berbintang Di Provinsi Bali).E-Jurnal Ekonomi dan Bisnis, Universitas Udayana 5.1 (2016): 115-142.

Sugiyono. (2017.) Metode Penelitian Kualitatif dan Kuantitatif dan RED. Jakarta: Alfabeta

Surendran, P. (2012). Technology Acceptance Model: A Survey of Literature. International Journal of Business and Social Research (IJBSR), 2(4), 175-178.

Surya, Anak Agung Made dan Suardikha, I Made Sadha. (2016). Faktor-Faktor Yang Berpengaruh Pada Kepuasan Pengguna Sistem Informasi Akuntansi Lembaga Perkreditan Desa Di Kecamatan Mengwi. E-Jurnal Akuntansi Universitas Udayana, 15(1), pp: 317-348

Suroso, H dkk.(2017). Faktor-Faktor Yang Mempengaruhi Partisipasi Masyarakat Dalam Perencanaan Pembangunan Di Desa Banjaran Kecamatan Driyorejo Kabupaten Gresik. Wacana -Vol. 17, No. 1. 
Suryawarman, Kameswara dan Widhiyani, Ni Luh Sari. (2013). Faktor-Faktor yang Mempengaruhi Kinerja Sistem Informasi Akuntansi Pada Restoran Waralaba Di Kota Denpasar. Jurnal Universitas UDAYANA vol.2 no. 1 Januari 2013.

Terry, Julian and Craig Standing. (2004). The Value Of User Participation In Ecommerce System Development. Informing Science Journal 7. Tian-Hui, Zhu. 2009. Library User Education Under The Circumstance Of Network. UsChina Education Review 6 (12).

Widarno Bambang, (2008). Efektivitas Perencanaan Dan Pengembangan Sistem Informasi. Universitas Slamet Riyadi. Surakarta.

Yuadi, Imam (2008) Kualitas Perangkat Lunak: Definisi, Pengukuran dan Implementasi (Studi kasus dalam open-source software)". 